\title{
LEGAL LIABILITY FOR WATER FLOODING IN PETROLEUM RESERVOIRS IN ALBERTA
}

\author{
E. M. Bredin*
}

\section{The technique of water flooding:'}

McElroy ${ }^{2}$ says that it has been estimated that California thus far (1955) has produced nearly 10 billion barrels of oil and has wasted at least 10 billion barrels. This waste consists of leaving oil in the ground irrecoverable by economic means now known. It is irrecoverable because reservoir energy is not avaiblable to bring it to the well bore.

Oil and gas are brought to the well bore in the reservoir by one or more of three energy sources identified by William J. Murray as (a) dissolved gas drive; (b) gas cap drive; (c) water drive.

Many reservoirs are underlain by water. Water, oddly enough, is compressible, particularly in large quantities and at extreme pressures. In such a reservoir the differential in pressure resulting from the expansion of the com. pressed water at the point where an oil well pierces the reservoir forces the oil to the surface. The preservation of this water drive is essential if maximum production of oil is to be obtained.

In primary production of oil, that is, production without any artificial maintenance of pressure in the reservoir brought about by injection of liquids or other substances, a reasonable recovery is $15 \%$ to $25 \%$ of the oil in place. The use of water flooding in a suitable reservoir can bring the percentage of oil recovered to as much as $50 \%$ of the original oil in place. Miscible flood techniques are even more efficient.

Water flooding, as an oilfield practice, began about the year 1907 after observations made in the Bradford Field in Pennsylvania revealed that water draining into oil wells, probably from a leaking casing or improper plugging, increased the recovery of oil. These observations led operators to undertake water flooding by artificial means. The results were so encouraging that systematic artificial water flooding was widely tested and in 1921 the State of Pennsylvania passed legislation permitting water flooding.' In consequence of the Pennsylvania experience, the use of water flooding rapidly spread to

-E. M. Bredin, Q.C., is General Counsel, Mobil Oil of Canada, Ld., Calgary. Paper delivered to the Calgary Oil and Gas Lawyers Association, October 1960. He wishes to acknow. ledge his indebetedness to J. J. Justen and James Warke of the Production Department for technical assistance in the preparation of this paper and to $W$. MacInnes of the Law Department of Imperial Oil Limited at Calgary for many helpful references.

- IWater flooding has been defined as "the diligent, controlled injection of water into an oil producing stratum for the purpose of increasing the percentage and rate of recovery of oil from the stratum". Fancher, The Development of Operation of Secondary Water Flooding Project, A.P.I. Bulletin 48 (1942) cited by Hughes in Legal Problems of Water Flooding, Recyeling and Other Secondary Operations, Ninth Annual Institute, Southweatern Legal Foundation, p. 105.

2 Water Flooding of Oil Reservoirs, Thomas K. McElroy Vol. 7 No. 1 Baylor Law Review, p. 18 (winter 1955).

Engineering Aspects of Unit Operation, Third Annual Institute, Southwestern Legal Foundation, p. 1, cited by Raymond Myers in The Law of Pooling and Unitization, at p. 24.

McElroy Opus cir., p. 20. 
other states and to Canada as a means of secondary recovery or pressure maintenance. ${ }^{3}$

The purpose of a water flood is to flush oil from the porous rock or sand in the reservoir and force that flushed oil towards the well bore. Various techniques are employed to achieve this end. It should be pointed out, however, that not all reservoirs are suitable for water flooding." The composition of the water used in the flood may vary. In some areas salt water is employed and in others fresh water from rivers or other surface basins is used; then too, water recovered from another formation may be injected in the reservoir. Great care must be taken to ensure that the water used is free from sediment and harmful impurities. A common technique is that known as the five-spot pattern. In the five-spot pattern, a well is located at each corner of an area designated for production. These four wells are known as injector wells and water is injected through them into the formation. In the centre of the rectangular pattern formed by these wells a producing well is located. Water forced under high pressure into the oil strata displaces the oil and forces it to the well bore of the producing well. Another pattern utilized in water flooding is that known as the "peripheral" pattern. In this method a line of input or injection wells is placed on the flank of a formation and the "sweep" carried forward by degrees with the oil being forced towards production wells. As the water creeps across the area to be flooded more and more producing wells are converted into injection wells until, eventually, all wells are flooded out.

\section{The right to undertake a water flood operation:}

A lessee may have the right under his lease to institute a water flood operation ${ }^{7}$ as an incident of the prudent and reasonable operation of the lease. In the United States it is generally agreed that a lessee may undertake such a project even without specific powers in his lease. This right results from the implied covenant in the oil and gas lease requiring the lessee diligently to develop the leased land. In this connection Merrill" states, "accordingly the covenant for diligent operation requires the lessee to employ such methods as are reasonably adapted to stimulate or increase production". He cites Livingstone Oil Corporation v. Waggoner" where the court held that "it was incumbent upon appellant to get all the oil possible out of the well and to use all legitimate means of doing so". Merrill ${ }^{10}$ points out that there are no restrictions on the methods of operating oil wells, citing $W$ cmple v. Producers Oil Company ${ }^{11}$ where Chief Justice Munroe of Louisiana said:

"the right to drill and operate wells is conferred in direct terms, and, as there is no restriction placed upon the method of operating, it is to be assumed that it was the intention that they should be operated by the method best calculated to accomplish the purpose for which the contract was entered into, to wit, that which would result in the production of the greatest quantity of oil or gas, or both;".

s"Pressure maintenance" refers to the injection of fluids early in the life of the field or reservoir before the dissipation of initial pressures or energics while the term "secondary recovery" refers to operations connected with the injection of fluids (or gases) after the completion, or neat completion of primary operations. Myers, Opus cit., p. 25.

"See Brown and Myers, Some Legal Aspects of Water Flooding, 24 Texas Law Review, at p. 458.

TFor suitable lease wording see Brown and Myers Opus cit., at p. 469.

8Merrill, Covenants Implied in Oil and Gas Leases, (2nd Ed. 1940), p. 192.

${ }^{0} 273$ S.W. 903 (Texas Civil A. 1925); Merrill, Opus cit., at p. 193.

10 Opus cil, at p. 192.

11145 La. 1031. 83 S. 232. 
Brown and Myers ${ }^{12}$ say:

"Hence it may be assumed that the right to water flood as an efficient producing method, exists under the terms of the usual oil and gas lease whether or not any specific mention thereof is made in the lease."

\section{Commenting on this statement, Merrill, in his supplement says: ${ }^{13}$}

"The:e can be no quarrel with the position taken by the learned authors but it must be remembered that every such project must stand on its own feet with respect to whether it is or is not a prudent method of operation, and that the duty of exercising diligence and prudence applies to the operation of the water flooding project itself."

But while the lessee has the right to institute water flooding procedures with. out the consent of the lessor, he may find himself subject to action by the lessor where production wells from which the lessor has been deriving royalty have been turned into injection wells. In the case of Ramsey v. Carter Oil Company ${ }^{14}$ the court enjoined the lessee from converting an offset well to a gas injection well. In Carter Oil Company v. Dees ${ }^{15}$ the lessee brought action for a declaration that it was entitled to convert an offset producing well into a gas injection well. Both of these cases scemed to turn on whether or not there was a likelihood that the lessor would be deprived of oil as a result of the operation. In the Dees Case, the court held that the prime purpose of a lease is royalty reserved to the lessor and that the court must determine whether the lessee's proposed operations tend to defeat the purpose of the lease or are within the scope of the rights granted in the lease. The court said:

"The contract being silent as to the methods of production, it must be presumed to permic any method reasonably designed to accomplish the purpose of the lease; the recovery of oil and the payment of the royalty. The court would violate fundamental principles of const:uction to insert by implication a provision that lessee is limited to production of such oil as can be obtained by old fashioned means, or by so-called 'primary operations' . . . . They (lessors) argue that the migration of oil from the offset well is decisive regardless of other conditions. The argument is novel, net only in the position that the court should consider only one condition in determining whether the op:ration is reasonable, bue also in taking a principle of law designed to secure diligence in development of a field, and asserting it as a reason to limit and curtail productive operations .... An implied provision, such as the above (prudent operations) is asserted to carry out the manifest intention of the contract. For this reason, there cannot be an absolute and unqualified obligation to establish an offset well, or any other well, regardless of circumstances. All the pertinent conditions must be considered by the court.... We hold the basic rule remains; the lessee should do what a prudent operator, using reasonable diligence would do, having in mind the best interests of the lessor and the lessee. As this rule has been applied in determining whether an operator is obliged to establish an offset well, so it should be applied in deciding whether he shall be required to maintain it, or be permitted to discontinue it ... . The operator has diligently and effectively developed the property, and now has a vested right to complete the extraction of oil, provided it does so in the manner of a fair and prident operator."

McElroy" states that there are two statements in the Decs opinion that should be repeated and emphasized:

"(1) there is no unqualified obligation of the lessee to maintain any particular well; the prudent operator rule would be applied in determining whether the well should be continued or discontinued; and (2) the operator has a vested right to complete extraction of the oil if he can do 30 as a prudent operator."

In Alberta the failure to institute a water flood or other secondary recovery operation may well constitute wasteful operation under s. 2 (u) (iii) and

1:Opus cit., p. 469.

131950 Supplement p. 18.

1174 Fed. Supp. 481, affirmed 172 Fed. 2d 622.

1692 N.E. 2nd 519.

${ }^{16}$ Opus cit, p. 40. 
(iv) of the Oil and Gas Conservation Act. ${ }^{17}$ The Conservation Board has power, under the Act, to shut in any well if, in its opinion, waste can be prevented or if the well is being operated in such a way that any provision of the Act is contravened. ${ }^{18}$ Further, the Board may approve a water flood operation under s. 38 of the Act and may require it by an order under s. 37. ${ }^{\text {.*a }}$

\section{Proof of injury from water flooding:}

The escape of water will become apparent to the adjoining lessee or owner when a break-through of water takes place and increasing quantities of water are recovered in the production of oil from his well. Ultimately his well may become incapable of producing oil commercially. Apart from the reduced recovery of oil, he will be put to the expense of treating the oil for removal of the water. His remedy will be an action in the courts for damages or for an injunction, or for both, ${ }^{19}$ and possibly an application to the Oil and Gas Conservation Board to rescind an approval granted by the Board for the water flood project.

One of the deterrents to an action of this kind, apart from the problems of liability, is the difficulty inherent in establishing the plaintiff's claim. To prove the source of encroaching water which enters a lease at a point many thousands of feet below the surface may, in some cases, be impossible. Particulary is proof difficult where several water flood projects are carried out in the vicinity of the plaintiff's land. This difficulty of proof may explain why, as Mr. Huges points out, ${ }^{1,2} 175$ water flood projects have been carried out in the south-eastern counties of Kansas alone without any agreements and, apparently, with few, if any, controversies.

One technical development may give rise to a defence of contributory negligence in such actions. This development is known as "hydraulic fracturing". Inl This technique can be carried out in various ways of which, perhaps, the best known is "sand fracing". This method involves forcing sand, under great pressure from the well into the producing formation. The effective permeability is increased and a heavier flow of oil to the well bore results. Where this technique is used, and especially in those cases where excessive force is applied, a situation can result known as "well-to-well fracturing". In other words, the explosive force may fracture the reservoir so as to open a channel from the fractured well toward an injection well in a water flood project. Along this channel water from the injection well may reach the well bore of the fractured well. Because this escape of water would not have occurred apart from the fracturing the plaintiff is, to some extent at least, the

17 Stacutes of Alberta 1957 c. 63: "wasteful operations" means ...

(iii) the inefficient, excessive or improper use or dissipation, of reservoir energy however caused.

(iv) the failure to use suitable artificial, secondary or supplementary recovery methods in a pool where it appears probable on the basis of available itnformation, that such methods would result in increasing the quantity of oil or gas ultimately recoverable from the pool under sound engineering and economic principles.

13/bid, 3. 40. See also the provisions of s, 127.

18aFor the effect of such an approval or order on the liability of the operator, see p. 530, post.

${ }^{19}$ See p. $\mathbf{5 3 1}$ post for further discussion on this type of action.

100 Opus cit. p. 138.

10b For two recent cases on this development see Holmes v. Delhi-Taylor Oil Corporation (Tex. Civ. app. 1960) 377 S.W. $2 d 479$ and Delhi-Taylor Oil Corporation v. Gregg (Tex. Civ. app. 1960) 337 S.W. 2d 216. 
author of his own damage. Some reservoirs have naturally existing fracture systems so that channels exist for considerable distances underground. The Steelman Field and the Weyburn Field in south-eastern Saskatchewan are two examples of this phenomenon. Water injected in a well in these fields may damage a well a considerable distance away by following the natural fractures. The question of liability could then become one of negligence based on whether the defendant knew, or ought to have known, of the existence of these fractures.

The case of Comanche Duke Oil Company v. Texas Pacific Coal and Oil Company, ${ }^{20}$ involved the shooting of an oil well in order to increase production. It was alleged that an excessive amount of nitro-glycerine had been exploded in the defendant's well with the result that the plaintiff's well on an adjoining tract was flooded with water. The Texas Commission of Appeals decided the case on negligence and causation, and stated that knowledge of the surrounding circumstances had some bearing on the degree of diligence required to meet the ordinary standard of care.

In Empire Oil and Refining Company v. Hoyt ${ }^{21}$ the lessor sued the lessee for damages for negligently acidizing an oil well. It appeared that the limestone formation separating the oil and salt water was only 1.2 to 2.5 feet in thickness, and if the situation had been known before acidization treatment a blanket of calcium chloride would have been laid down. The well was acidized without such precautions with the result that the oil bearing strata became so impregnated with salt water that the leasehold was rendered useless for oil production. The court held that the lessee was liable for breach of the implied covenant to use due care even though the work was done by an independent contractor. In a note on this case, Earl A. Brown, Jr. says: ${ }^{\text {"2 }}$

"A method may be used under such circumstances that its use is termed negligent. But it is believed that the use of an established method of operation, such a acidization, under usual and ordinary circumstances, cannot be deemed negligent. To constitute negligence in these cases there must be the 'additional element of knowledge' of some fact or circumstance which makes the use of the established mcthod in that situation negligent."

4. The analogy of the flooding of underground mines by subterranean waters: Brown and Myers" ${ }^{23}$ refer to the

"strong analogy in cases dealing with the flooding of underground mines by subterranean waters. In this connection it may be stated, as a general proposition, that the law relating to the flooding of lands generally will apply to the flooding of mines, and where the owner of a mine does nothing more than permit water to flow where it naturally would go in the ordinary course of mining, he is not liable for damage to adjoining mines for injuries due to percolation or gravitation of such water, especially where this cecurs simply by reason of the removal of coal from a mine. But if the owner of one mine conducts into the adjoining mine water which would otherwise not go there or causes it to go there in larger quantities than it would go naturally, he commits a wrong which the law will redress."

The learned authors then quote a number of American cases supporting their view. These cases and the above statement coincide with the view of English authorities." In Baird v. Williamson ${ }^{25}$ the defendant's mine was on a higher level than the plaintiff's, and the plaintiff alleged that the defendants made openings in the strata into which large quantities of water were pumped which

"2uTex. Comm. of App. (1927), 298 S.W. 554.

2112 Fed. 2d 356, C.C.A. 6th 1940.

$\because 19$ Texas Law Review, p. 85.

23Opus cit. p. 466.

24See Smith v. Kendrick, 7 C.B. 515, 137 E.R. 205; A cton v. Blondell, 12 M. \&. W. 324.

215 C.B. (N.S.) 376, 143 E.R. 831. 
encroached on the plaintiff's mine. There was no allegation of negligence in the conduct of operations in the defendant's mine. Chief Justice Erle said:

"The defendant, as occupier of the higher mine, has not the right to be an active agent in sending water into the lower mine."

After pointing out that if nature sent the water down the defendants would not be responsible, he continued:

"The law imposing these regulations for the enjoyment of somewhat conflieting interests does not authorize the occupier of the higher mine to interfere with the gravitation of the water so as to make it more injurious to the lower mine or advantageous to himself. This appears to us to be law. For authority we referted both to Smith v. Kendrick and also to the question left to the jury in Acton v. Blondell."

While the Court of Appeal in Alberta has stated that some of the reasoning in the cases of Smith v. Kendrick and Acton v. Blondell is not law in Alberta, ${ }^{20}$ nevertheless the decisions in these cases are applicable. It therefore appears that causing the flow of water on to the lands of another so as to damage those lands as, for example, by means of water injection, is actionable. The basis of liability must be found in the rule of Rylands v. Fletcher, ${ }^{27}$ negligence, nuisance or trespass.

4. Rylands v. Fletcher:

McElroy ${ }^{28}$ states that in the cases of Turner v. Big Lake Oil Company ${ }^{20}$ and Cosden Oil Co. v. Sides ${ }^{30}$ the Texas Courts emphasized that the production of oil and the storage of water in Texas were essential to the property of the State and that the construction of salt-water pools and drilling of oil wells in the usual and appropriate way were natural uses of Texas land, and they repudiated the doctrine of strict liability in the case of unnatural uses of land enunciated in Rylands v. Fletcher. McElroy" says:

"The advanced state of the petroleum industry into secondary recovery operations and the necessity for strict conservation practices must require the conclusion that the water flooding of oil and gas producing land is a natural and appropriate use of such land. That being true, liability of the operator for causing water encroachment upon adjoining lands must be predicated upon either negligence or unreasonableness. In either event a fact question is presented and the rule of absolute liability should not be applicable."

In Comanche Duke Oil Company v. Texas Pacific Oil Company ${ }^{31 a}$ the Texas court refused to treat the explosion of nitro-glycerin in a well as a situation to which the rule in Rylands v. Fletcher applied. In the Alberta case of Christa v. Marshall and Christa v. Ferguson and Ferguson ${ }^{31 \mathrm{~b}}$ it was urged on Parlee, J. that the drilling of artesian wells which resulted in surplus water draining on to the land of another was a situation to which the case of Rylands v. Fletcher was applicable. Parlee, J. held that the drilling of the artesian wells was a natural use of lands but imposed liability for the escape of water because the defendants had increased the natural servitude to which the plaintiff's

2"i.e., concerning the drainage of natural surface waters, sec Beck, J. in Makowecki v. Yachimyc, [1917] I W.W.R. 1279 at p. 1294. Sec also footnote at p. 1297, and see Farnell v. Parkes, [1917] 3 W.W.R. 882,Townsend \& Martin v. C.N.R., [1922] 1 W.W.R. I121 and Christa v. Marshall \& Christa v. Ferguson and Ferguson, [1945] 2 W.W.R. p. 44.

${ }^{1}$ (1866), L.R. Ex. 265, affirmed L.R. 3 H.L. 330.

IHOpus cit., at p. 36.

at)(1936), 128 Tex. 155; 96 S.W. 2d 211, affirming 62 S.W. 2d 491.

sogastland C.C.A. (1931), 35 S.W. 2d 815; 15 Texas Law Review 355; 20 Texas Law Review 399.

31 Opus cit., at p. 36.

s1aTex. Comm. of App. (1927), 298 S. W. 554.

giv[1945] 2 W.W.R. 44. 
land was subject. It is submitted that since, under The Oil and Gas Conservation Act, the failure to initiate pressure maintenance operations and the inefficient use or dissipation of reservoir energy are wasteful operations and since such projects are only undertaken with the approval of the Oil and Gas Conservation Board, it should not now be held by any court that water flooding, where reasonably deemed necessary, is an unnatural use of land to which the rule in Rylands $\mathrm{v}$. Fletcher is applicable.".te

\section{Some United States cases dealing with water flooding:}

In Sunray Oil Co. v. Cortez Oil Company, ${ }^{32}$ Cortez sought to enjoin Sunray from disposing of salt water on a ten acre tract leased by Sunray. Cortez was the owner of the minerals on adjoining lands and claimed that the salt water might find its way to his land and ruin potential oil or gas reservoirs. The trial court granted an injunction but on appeal the injunction was dissolved on the theory that the alleged damage was speculative and theoretical only. The court relied on the earlier case of Tidal Oil Co. v. Pease." In that case the court had held

"Subject to the rules of law with reference to due care, etc., the owner of land ought not to be prohibited from the full use and benefit of his land so long as he does not, by such use, injure or damage other persons."

In the case of West Edmond Salt Water Disposal Association v. Rosecrans, the defendant was injecting salt water into an abandoned well in a tract adjoining the plaintiff's land. The plaintiff alleged that the water was cntering his land and brought action on three counts, first for ejectment, second for a judgment for profits made, and third for exemplary or punitive damages. The jury brought in a verdict on all three counts but the trial court disallowed the exemplary damages. The appeal court held that the defendant had a right to inject salt water and the injection itself did not amount to a trespass. The court further held that in injecting the salt water into the wells the defendant was acting in a lawful manner and within his rights, and the exercise of such rights did not give rise to a cause of action so long as there was no injury or damage to the plaintiff's lands and so long as the plaintiff was not deprived of the use or enjoyment of those lands. The only liability that co:nld exist would be for actual damage to the plaintiff's land. The court held that once the salt water went into the formation the defendant lost title to it. The court further held that on the facts the defendant was acting in a lawful manner and in the exercise of his lawful rights, and did not injure or damage the plaintiff's lands in any way. The Supreme Court of the United States ${ }^{35}$ dismissed the appeal.

In West Edmond Hunton Lime Unit v. Lillard ${ }^{30}$ the unit was injecting great quantities of salt water into a formation. After the flood was underway the plaintiff acquired, by assignment, a loase of certain lands on which two gas wells were located. These wells had produced from another formation.

arcFor a full discussion dealing with the escape of deleterious substances see Escape of Deleterious Substances: Strict Liability y. Liability Based Upon Fanlt, by l.ee Jones Jr., First Annual Rocky Mountain Mineral Law Institute, p. 162.

32112 P. 2d. 792, (Okala, Sup. C. 1941).

3s (1931) 153 Okla. 137, 5 P. 2d. 389, p. 393.

34(1950) 204 Okla. 9, 226 P. 2d. 965.

35340 U.S. 924.

${ }^{3 a}(1954) 3$ O. \& G.R. 1426, 265 P. 2d. 730, Okla. Sup. Ct. 
The plaintiff tried to produce his two wells but could not because the salt water injected by the defendant penetrated into the sub-surface of his lands and destroyed the productivity of the wells. The defendant demurred to the plaintiff's claim for damages for loss of production. The plaintiff raised a second cause of action by alleging that he had to abandon casing from one of the wells because pulling the casing resulted in salt water flowing out over the surrounding land. He was given judgment on this second cause of action. No appeal was taken from the demurrer in the first cause of action. In this case the plaintiff appears to have suffered damage in his inability to produce the two wells. It appears, too, that the plaintiff had acquired his leases without knowledge that the defendant was injecting large quantities of water underground. Nevertheless, while the court stated that the plaintiff could recover any actual damage or injury resulting from the water flooding, on the facts recovery was only granted with respect to the loss of casing. This case is difficult to reconcile with the Rosecrans Case.

Hughes ${ }^{\text {a7 }}$ refers to an unreported case in Kansas where the defendant Brundred Oil Corporation applied for and received permission from the Kansas Corporation Commission to institute a water flood. Part of the plaintiff's land was involved. The plaintiffs drilled several wells on adjoining lands, not under lease to the defendant, and brought action alleging that salt water injected by the defendant had escaped to a formation underlying the plaintiffs' lands not under lease to the defendant. The plaintiffs did not claim that there was any negligence or that the flood had been conducted in violation of any rules of the Corporation Commission. The defendant contended that the Statutes of Kansas absolved it from liability in the absence of negligence or violation of the orders of the Corporation Commission. It appeared that the plaintiffs had drilled their wells after the water flood had started and with notice of the permit to flood. It also appears that the plaintiffs were attempting to obtain the benefit of the defendant's water flood. The defendant took the position that it was absolved by the order of the Kansas Corporation Commission and also alleged that the plaintiffs had failed to exhaust their administrative remedies by not first appealing to the Corporation Commission. Mr. Hughes states that the court gave no written judgment but he believes that the court at least gave consideration to the allegation that the plaintiffs had failed to exhaust their administrative remedies.

In the recent Illinois case of Reed $v$. The Texas Company an injunction was sought by a number of producers in an oil pool to restrain the other producers in the pool from proceeding with a water flood program in connection with a unit. The plaintiffs had refused to join the unit. The plaintiffs argued that they had not joined the unit and contended that oil to which they had title would be forced to flow to wells owned by others, and that the operation was illegal. The defendants contended that they were proceeding according to law and that to discontinue the water flood would result in great loss to the producers and to the royalty owners. The court referred to the Ramsay and Dees cases and said: ${ }^{30}$

37Opus Cit., at p. 133.

38159 N.E. 2d. 641, 11 O. \& G.R., p. 789.

so11 O. \& G.R., p. 792. 
"If a minority of one or more persons affected by the operation could prevent it by refusing to join in the agreement they could then force the others to choose between leaving a large part of the oil undergrcund, or consent to granting the dissidents an unreasonably large percentage of the oil. In other words, the power to block a repressuring program by tefusing to sign the unitization agreement would be the power to insist upon unjust enrichment. Surely a court of equity should not support such a rule."

The court held that the question of title to the oil was irrelevant. In answer to the plaintiffs' argument that the operator has an absolute duty to prevent any migration of oil even though the plaintiff is compensated by other oil, the court held that an operator must be reasonably diligent to prevent waste and to prevent any substantial loss of oil, but that the absolute prevention of any movement of oil underground across a boundary line is not humanly possible. It further held that if the oil moving from one lease is compensated by a substantially equal amount from the same pool there is no actual loss. Since the legislature has recognized the propriety of secondary recovery procedures if done in a reasonable and fair manner with supervision and control assigned to the mining board, the court's duty was only to see that a fair and reasonable plan existed and to remedy any substantial defect. Because the plan had been approved by the Board and no defects were shown, the action for an injunction was dismissed.

In a footnote to the case in Oil and Gas Reporter ${ }^{\text {ana }}$ the following appears:

"The significance of the superior bargaining position of a small minority of persons who do not join in the unitization agreement is recognized by the court. To grant an injunction in this case would in effect force the majority to choose between leaving a large part of the oil in the ground or consent to granting the non-consenting minority an unreasonably large percentage of the oil. Another formidable reason exists as an additional basis for the denial of injunetive relief in that such conduct would lead to physical waste of the mineral. Conservation of the natural resources of the state requires continuing judicial support as was given in the principal case."

\section{Negligence:}

In summary of these cases, it seems that while an action will undoubtedly lie where a water flood project, though approved by the conservation authority, is conducted negligently or where negligence exists in any phase of the flood, negligence is seldom relied on as the basis of decision. Probably the difficulty of proof and availability of grounds of liability without fault account for the small percentage of cases in which negligence has been a deciding factor.

\section{Nuisance and trespass:}

An examination of the nature of the interest conferred by the usual oil and gas lease is essential to a consideration of the question whether the lessee may bring an action in nuisance or trespass if the leased lands are damaged as a result of a water flood operation.

Confusion has existed in the courts concerning the nature of the oil and gas lease, and as Professor Thompson says: ${ }^{10}$

ana110 \& G.R. 794.

avbFor a further discussion on United States cases on this subject see: "Tort Liabilities in Secondary Recovery Operations" by Lee Jones, Jr. 6th Annual Rocky Mountain Mineral Law Institute, p. 639j "Problems Incident to the Acquisition, Use and Disposal of Repressuring Substances Used in Secondary Recovery Operntions" by Roscoe Walker, Jr. 6th Annual Rocky Mountain Mineral Law Institute, p. 273; "Rights and Liabilities on Subsurface Operations" by Wm. Jarrel Smith 8th Annual Institute on O:I \& Gas Law and Taration S.W. Legal Foundation, p. 1.

"The Nature of the Oil and Gas Lease-A Statutory Definition, Alberta Law Review No. 5, Spring 1960, 463. 
"The oil industry and practitioners welcomed the 1957 decision of the Supreme Court of Canada in Berkbeiser v. Berkheiser" for its clear statement of the nature of the interest confered by the 'unless' type of oil and gas lease as a "profit à prendre.."

The interest might further be described as a several profit à prendre in gross. It is several because it gives, even as against the owner of the land, exclusive right in the lessee to recover the oil and gas granted by the lease.

\section{Halsbury says: ${ }^{42}$}

"The right constituting the profit a prendre may be exercisable to the exclusion of all other persons in which case it is sa:d to be a right in severalty or a several profit à prendre."

The right is in gross since it is not appurtenant to other land and exists independently of any other estate in land. An analogous profit a prendre is the right to a several fishery in a river or stream. A great many cases dealing with several fisheries have been decided and they are most helpful in determining the nature of a profit à prendre.

One who receives the grant of a several fishery is given the right to fish in a limited area of the river and to recover fish from that portion of the river. The fish may well migrate to other areas in the river and fish may come from other areas to the area in which the grant is given. The problems brought about by the fugacious nature of oil and gas are akin to the problems of ownership of fish in a several fishery. Cases on several fisheries established that the holder of a profit à prendre can bring action in both trespass and nuisance for interference with his rights. In Hindson v. Ashby ${ }^{43}$ Lord Justice Lindley says:

"Both upon principle and according to the authories"t a several fishery may exist in a public navigable river either apart from or as an incident to the ownership of the soil over which the river flows. Moreover the cwner of a several fishery, whether he owned the soil or whether he did not, could maintain trespass for a disturbance of his right of fishery; for, even if he did not own the soil, his several fishery was in incorporeal hereditament and a p:ofit a prendre for the disturbance of which trespass was the appropriate remedy."

In Fitzgerald v. Firbank" Lord Ebury had given the Waltonian Society an exclusive right for a term of years to fish in a defined part of his stream. The plaintiffs, acting for the Society, alleged that the defendant had interfered with their right to fish by dumping water loaded with sediment into the stream, the effect of which was to drive away the fish and prevent their spawning. The defendant's answer was that he had not prevented the Society members from fishing. In the court of Appeal Lord Lindley says: ${ }^{43 n}$

"The righe of fishing includes the righe to take away fish unless the contrary is expressly stipulated. I have not the slightest doubt about that. Therefore the plaintiffs have a right as distinguished from a mere revocable licence. What kind of a right is it? It is more than an easement. It is what is commonly called a profit a prendre, and it is of such a nature that a person who enjoys that right has such possessory rights that he can bring an action for trespass at common law for the infringement of those rights. The law on this subject was very carefully considered and will be found laid down in Holford v. Bailey is in the Exchequer Chamber."

Lord Lindley then asks:

"Does the running of the dirty water, into the fishery constitute an incerference with the plaintiff's rights or is it what is called a damnum absque injuria?"

41 [1957] S.C.R. 387.

4'Halsbury (2d. Ed.) Vol. 11, Para. 672, p. 383.

4 [1896] 2 Ch. 1 at p. 10.

${ }^{44} \mathrm{He}$ sefers to the following authorities: Smith v. Kemp, 2 Salk 637; Seymour v. Lord Courtenay, 5 Burr. 2815; Holford v. Bailey, 13 Q.B. 426, 116 E.R. 1325 and Duke of

Somerset v. Fogwell 5 B. \& C. 875.

15[1897] 2 Ch. 96.

45albid., at p. 101.

13 Q.B. 426, 116 E.R. 1325. 
and answers by saying:

"It (damnum absque injuria) cannot be so if I am right in the first proposition that the plaintiffs have rights and that these rights have been damnified by fouling the tiver. The defendant had no right to foul the river to the damage of anybody who has rights in that river. He is a mete wrongdoer; though if the plaintiffs had no rights in the river of course they would have had no right legally to complain. This is a somewhat unusual case and I am not aware of any precedent for what I may describe as an action of nuisance by the owner of a sole and exclusive right of fishery but once grant that the owner of such a right can sue in trespass with one kind of infringement of it then I cannot see why he might not maintain an action on the case for nuisance at common law for such an interference with his right as is proved in this case."

Lord Justice Rigby says: ${ }^{40 \mathrm{a}}$

"To give the plaintiff a sole and exclusive right even for an hour a deed was necessary; and that would be a grant and, whether the grantee of the fishery had it in fee or for a term of years or even an hour he could sue for disturbance during the time that the interest under his grant continued .... That same passage also lays down what I conceive to be undoubted law that the grantee in such a case may sue for disturbance."

In answer to the argument that the plaintiff could not sue in trespass but had to sue on the case, Lord Justice Rigby said at page 104:

"I hold that the grantces of the incorporeal hereditament have a right of action against any" person who disturbs them either by trespass or by nuisance or in any other substantial manner."

It appears clear therefore, that both nuisance and trespass will lie for the interference with a profit à prendre.

What form of action should then be adopted by a plaintiff whose oil and gas lease has been interfered with by a water flood project on adjoining property? To distinguish between trespass and nuisance in the framing of the action, it is necessary to deal to some extent with the historical background of these two old forms of action. F. H. Newark, in an article entitled The Boundaries of Nuisance," says that the truest dictum in the books is that of Chief Justice Erle when he said:

"The answer to the question-'What is a nuisance?' is 'immersed in undefined uncertainty'."

Newark points out that the problem today is due to the fact that there has been an improper extension of the term nuisance to cover cases which have little in common with the original conception of that tort. He points out that disseisina, transgressio and nocumentum covered the three ways in which a man might be interfered with in his rights over land. Wholly to deprive a man of the opportunity of exercising his rights over land was to disseize him, for which he might have recourse to the assize of novel disseisin. But to trouble a man in the exercise of his rights over land without going so far as to dispossess him was a trespass or a nuisance according to whether the act was done on or off the plaintiff's land. Thus to go on the plaintiff's land and demolish a weir was a trespass which gave rise to an action in trespass; to stay on your own land and demolish a weir to the hurt of the plaintiff was a nuisance for which the assize of nuisance was the proper remedy. Nuisance could never be committed on the plaintiff's land; an act done on the plaintiff's land would be disseisin or trespass according to the circumstances.

Winfield ${ }^{\text {'s }}$ says:

"Although we hear no more of the problem in the reports in the shape of a dispure whether the trouble began on the land of the plaintiff or on that of the defendant, that is only because it was merged in the wider question, was the damage direct or consequential and in later cases this was made the vital distinction between trespass and case."

40a[1897] 2 Ch. 96, at p. 103.

${ }^{465}$ L.Q.R. 480

48Winfield on Tort, 6th Ed, at p. 577. 


\section{Winfield ${ }^{10}$ says:}

"The leading textbooks are in direct conflict on the relation of nuisance to trespass. According to one view these two torts may possibly coincide, some kinds of nuisance being also trespass to land. According to another view they are mutually exclusive."

\section{Street ${ }^{\text {so }}$ says:}

"Nuisance and trespass do not overlop. The influence on (sic) the old forms of action persists here, so that if injury to land is indirectly caused by the defendant, it cannot be trespass."

It has generally been conceded that the flow of water from one property to another amounts to nuisance and not trespass. In the case of Leveridge v. Hoskins," the defendant dug ditches which diverted a river onto the plaintiff's land. It was held that the damages were presumed to be consequential and therefore nuisance was the proper action. In the case of Reynolds v. Clarke the court held that the diversion of water onto the plaintiff's land by the defendant was a nuisance and not a trespass. Similarly, in Haward v. Bankes the court held that immediate damage to the plaintiff's property is a ground for trespass; consequential damage to it is a ground for case.

Street ${ }^{54}$ points out the difficulty of distinguishing between direct and consequential acts. He says:

"How difficult it is to draw the line between "direct" and "consequential" acts is shown by Gregory v. Piper ${ }^{55}$ which held that it was trespass where rubbish, which was placed near the plaintiff's land, on drying, rolled on to it because this was the result of natural forces."

In contrast, Lord Justice Denning and Lords Radcliffe and Tucker in the case of Southport Corporation v. Esso Petroleum Company Limited ${ }^{50}$ held that where oil was discharged from a ship and was carried on the tide to plaintiff's foreshore the damage was consequential and not direct. Similarly, in the New Brunswick case of Mann v. Saulnier, ${ }^{, 7}$ where a fence post which was erect when originally placed on the boundary line, later leaned onto the plaintiff's land as a result of natural forces, it was held that the injury was consequential and not direct, and at most constituted a nuisance.

The problem of distinguishing between direct and consequential damage was recently reviewed in the judgment of Riley, J. in the Alberta case of Allen Phillips v. The California Standard Company, and Seismotech Ltd., and Sohio Petroleum Company." In that case the plaintiff's water well was allegedly damaged by seismic shots conducted by the defendants. The plaintiff based his action both in his pleadings and in his argument on the ground of trespass. Mr. Justice Riley referred to a quotation from Pollock on Torts," where Pollock says:

"In Hoare \& Co. v. McAlpineno Astbury, J. accepted a suggestion, not necessary to the decision, that the rule (i.e. Rylands $v$. Fletcher) extends to vibration set up in the soil by pile-driving (with the consequence of all damage therefrom being recoverable whether it amounts to nuisance or not); but this seems a fallacious extension. A man cannot be said to

$19 W$ infield on Ton, 6th Ed, at p. 576.

"OoThe Law of Torts, 2d. Ed., at p. 214.

011 Modern Reports 257, 88 E.R. 1025.

02 (1725), 1 Stra. 634, 2 Ld. Rym. 1399, 92 E.R. 410.

is (1760), 2 Burr. 1114, 97 E.R. 740.

BtAt p. 61.

$80(1829), 9$ B. \& C. 591.

of[1953] 2 All E.R. 1204, [1954] 2 All E.R. 561, [1955] 3 All E.R. 864.

57 (1959) 19 D.L.R. (2d.), 130 (N.B.C.A.).

5831 W.W.R. (N.S.) 331 .

6015 th Ed., at p. 377, cited by Mr. Justice Schroder in the case of Barratte v. Franki Compressed Pile Co. of Can. Lid. [1955] O. R. 413.

$0[1923] 1$ Ch. 167. 
bring or collect vibrations on his land, nor can th:y be said to escape; neither are they noxious or dangerous in their own nature. On principle the cause of action is nuisance or nothing and no authority can be shown for inventing any other."

Mr. Justice Riley then says; ${ }^{\text {ona }}$

"I am of the opinion that vibrations set up by the defendant and transmitted to land occupied by the plaintiff do not in law constitute a trespass, but do in law give a cause of action in
nuisance."

He points out that while the plaintiff had framed his action in trespass the court could, since the abolition of the forms of action, treat the action as having been brought in nuisance.

It seems clear that damage suffered as the result of encroaching water from a water flood project may give rise to an action in nuisance but not in trespass, and a plaintiff who is the grantee under an oil and gas lease holds an interest in the lands sufficient to warrant the bringing of such an action.

It might be assumed that the ordinary rule that nuisance is not actionable per se mighe apply in a case of this kind and that actual damage must be proved by the plaintiff in order to succeed. In result a heavy burden would be placed on the plaintiff because of the difficulty of proving the source and extent of his damage. Street" ${ }^{\text {"1 }}$ says, however, that there are two exceptions to the rule that actual damage must be proved in order to succeed in nuisance. One of these exceptions arises where the interference is with an easement, profit à prendre or right of access. Halsbury ${ }^{12}$ gives the basis for this exception as the danger that by the continuance of the illegal act an estoppel or limitation of action might render the illegal act lawful merely because of the inability or difficulty on the part of the plaintiff of proving special damage.

\section{Conclusion as to basis of liability for water flood:}

It seems apparent that a plaintiff in an action for damages sustained as a result of water flooding operations must, in order to succeed, frame his action in negligence or nuisance. It would appear that the principles ennunciated in $R$ vands v. Fletcher are not applicable to an action of this kind. It is submitted that the principles ennunicated in the mine flooding cases are, in reality, principles of the law of nuisance or negligence, and that these cases, apart from situations dealing with riparian rights and the rights of adjacent owners with respect to water flowing in defined channels, do not provide a basis of liability other than nuisance or negligence.

The United States courts take the view that so long as the defendant acts reasonably in carrying out his water injection operations he will not be held liable." ${ }^{119}$ The American Law Institute's restatement of the law of torts ${ }^{13}$ asserts that liability for interference with subterranean waters in the use of one's own property to the injury of another depends on whether the causative

Bra3I W.W.R. (N.S.) 331, at p. 335.

"12d. Ed., p. 215.

192Vol. 24, p. 21, para. 37 Sec. Ed. See also Harrop v. Hirst (1868) L.R. 4, Ex. 43. See also Street, 2d. ed., at p. 215.

wat The United States courts, too, recognize certain correlative rights as between producers in a common reservoir. One of these rights involves the complimentary duty not to injure the reservoir which is used in common with others. The production of oil without water flooding or other suitable pressure maintenance schemes may very well lead to damage to the reservoir, and affect all the producers in that reservoir. It follows, then, that water flooding is ordinarily a reasonable operation.

03Paras. 822 to 849, Restatement, Torts see also 29 A.L.R. 2d. 1357. 
activity or conduct (1) if intentional was unreasonable, or (2) if unintentional was negligent, reckless or hazardous. In Williams and Meyers text on oil and gas law, the authors state that what may be called a 'negative rule of capture' appears to be developing. ${ }^{\text {an }}$

"Just as under the rule of capture a landowner may capture such oil or gas as will migrace from adjoining premises to a well botcomed on his own land, so also may he inject into a formation substances which may migrate through the structure to land of others even if this results in the displacement under such land of more valuable with less valuable substance. (e.g. The replacement of wet gas by dry gas $^{\mathrm{at}}$.) The law on this subject has not as yet been fully developed, but it seems reasonable to suggest the qualification that such activity will be permitted, free of any claim for damages, only if pursued as part of a reasonable program of development and without injury to producing or potentially producing formations."

It appears that English courts view nuisance in much the same light as the United States courts. In Kine v. Jolly ${ }^{6.5}$ Vaughan Williams, L.J. stated that the English courts have always been unwilling in nuisance cases to hold that every nuisance, apart from the rule de minimis non curat lex, should be a cause of action, and that, on the contrary, the plaintiff's rights will not be enforced unless there has been a substantial interference .

Street ${ }^{\text {Ba }}$ says:

"A plaintiff does not win an action based on nuisance by showing merely that another is responsible for substantial interference with his land resulting in damage to him. Nuisance cases often deal with a conflict of interests between neighboring landowners, and so the law of nuisance has to adjust the respective rights and privileges of these neighbors."

The position has been expressed by Lord Wright in the House of Lords as follows: ${ }^{07}$

"A balance has to be maintained between the right of the occupier to do what he likes with his own and the right of his neighbor not to be inte:fered with. It is impossible to give any precise or universal formula, but it may broadly be said that a useful test is perhaps what is reascnable according to the o:dinary usages of mankind living in society."

Lord Wright's test of what is reasonable seems consistent with the American Law Institute's restatement which imposes liability for intentional water injection only if unreasonable.

\section{Effect of authorization of Oil and Gas Conservation Board:}

What has been said about liability on the grounds of nuisance and neligence has been said without regard to the effect of the provisions of The Oil and Gas Conservation Act." Under s. 37 of that Act the Oil and Gas Conservation Board has power to require the injection of water or other substances into the reservoir. Such an order may rake the form of an order requiring the operator to show cause why water injection should not be undertaken. An example of this type of order is Board Order No. Misc. 5013"18a which required certain operators in the Pembina Field in Alberta to show cause why they should not

63aWilliam and Meyers, Oil and Gas Vol. 1, Par. 204.5.

fuThis reference is no doubt to Tidewater Associated Oil Co. v. Stolt, 159 F. 2d 174. In this case, as a result of a cycling program, dry gas was injected into a producing formation. The plaintiff alleged that the wet gas in his lands was being displaced by the dry recycled gas. The plaintiff was unable to recover damages despite the ownership in place theory of the Texas courts. (See Theories of Ownership of Oil and Gas by J. H. Laycraft and Ivan L. Head, 31 Can. Bar Rev., p. 382.)

os[1905] 1 Ch. 480, 74 L.J. Ch. 174, affirmed Sub-nom. Jolly v. Kine [1907] A.C. 1.

002 d. ed. at p. 221.

'Tedleigh-Denfield v. O'Callaghan [1940] A.C. 880, at p. 903; [1940] All E.R. 349;

Cf. Trerett v. Lee, [1955] 1 All E.R. 406 (C.A.), espescially Bitketr, L.J., at p. 413.

cstatutes of Alberta 1957 c. 63.

csaAlberta Regulation 168/59, Alberta Gazette May 30, 1959, p. 324. 
institute flood operations. It is submitted that when this type of order is made, there is no liability either to third parties or to the lessor on the part of an operator who, being unable to show cause why the flood should not be undertaken, institutes water flood operations in compliance with the Board's requirements, assuming, of course, that there is no negligence in the carrying out of the operation.

Clerk and Lindsell on Torts, at page 604, states:

"Where a statute has authorized the doing of a particular act, or the user of land in a particular way, which act or user will inevitably involve a nuisance, all remedy whether by indictment or by action for damages resulting therefrom is taken away, providing every reasonable precaution cons'stent with the exercise of statucory powers has been taken to prevent the nuisance cccuring. The burden of proving that a nuisance is inevitable lies on the persons having a statutory authority. It is discharged by showing that all reasonable care and skill, acecrding to the state of scientific knowledge of the time, had been taken."

and at page 605:

"The statutory authority to commit a nuisance must, however, in order to afford a defence to the parties committing it, be expressed or necessarily implied."(141

It seems clear that where the defendant is carrying on a water flood without negligence pursuant to an order under $\mathrm{s}$. 37 either to show cause or otherwise, the defence of statutory authority is open to him. Section 119 (2) of the Act gives an appeal to the courts from an order under s. 37, but it is submitted that the fact of a possible appeal does not alter the statutory authority of the order.

In 1960 The Oil and Gas Conservation Act was amended by the addition of s. 38 (a) ${ }^{\text {io }}$. This section provides that the performance of any act required to be done under s. 37 of the Act or approved under s. 38 of the Act cannot be prevented or restrained by injunction or other order of the court. It is possible that an argument could successfully be made in the case of an appeal under s. 119 from an order made under s. 37, that, nothwithstanding a court finding that the order was made without jurisdiction, the injection of water could not be restrained by the court. Perhaps the better view is that if the order itself is quashed then the authority for the injection of water is taken away. The addition of s. 38 (a), without consideration of its effect on the powers of the appellate tribunal may, however, lead to some difficulties in interpretation.

Is the legal liability of one who injects water with the Board's approval under s. 38 of the Act any different from that of one who carries on the same operation under order of the Board pursuant to s. 37. In Metropolitan Asylum v. Hill ${ }^{11}$ it was held that authorization to construct a hospital for the sick and infirm poor did not authorize the bsilding of a small-pox hospital in such a place as to cause a nuisance to the adjoining owners. In Jones v. The Festiniog Railway ${ }^{\gamma 2}$ it was held that where the authority given is merely permissive a defendant is liable for nuisance even though not negligent in carry. ing out the permissive authority.

At first blush it would appear that the injection of water pursuant to the Board's approval under s. 38 is merely a permissive use upon which the benefit

"whe footnote cases are: $R$. v. Pease (1832), 4 B. \& Ad. 30; Vaughan v. Taff Vale Ry. (1860), 5 H. \& N. 679; Hammersmish Ry. v. Brand (1869), L.R. 4 H.L. 171; London, Brighton, elc. Ry. v. Truman (1885), II App. Cas. 45; Manchester Corporation v. Farnworth, [1930] A.C. 171.

701960 (Alta.) c. 74, s. 8.

71 (1881), 6 A.C. 193.

72(1868), L.R. 3 Q.B. 733. 
of statutory authority is not conferred. On the other hand, the purpose of The Oil and Gas Conservation Act is expressed in s. 4 to be the conservation and prevention of waste of the oil and gas resources of the Province. The committing of waste as defined has been made an offence under the Act. The purpose of a water flood is to prevent waste and to produce more effectively the available reserves of oil and gas. The Oil and Gas Conservation Board has, by the Act, authority over almost every phase of oil well and oilfield operation. While it is true that under s. 38 the order may be initiated by the applicant, any discretion on the part of the applicant thereafter ceases. The quantity of water proposed to be injected must be approved by the Board. The owner of a well must keep a record of the quanticies injected ${ }^{75}$ he must file a monthly report with the Board of the quantities injected and the source of the water, together with particulars of the treatment to which the water was subjected. It is submitted that The Oil and Gas Conservation Act is a complete code of oilfield operation and that the remedy of any person aggrieved is limited to an application to the Board to have the flood discontinued or modified particularly since the introduction of s. 38(a). The fact that The Oil and Gas Conservation Act is a complete code of procedure and that it was intended that civil rights should be taken away is further borne out by s. 125 which provides that the Lieutenant Governor in Council may direct the Board to prepare a scheme or schemes for the provision of compensation for persons who are injured by reason of any conservation orders made pursuant to the Act.

It is therefore submitted that even though a water flood, carried out pursuant to s. 38, would appear to be merely a permissive operation, the legislation is such as to have taken away not only the right to prevent, by court order, the injection of water but also any civil action by way of damages.

73Oil and Gas Conservation Act, Statutes of Alberta 1957 c. 63 3. 96. 